\title{
First-year English at The College of The Bahamas: Student Perceptions
}

\author{
Raymond A. Oenbring, Brianne Jaquette, \\ Christine E. Kozikowski, \& Ivy Higgins. \\ The College of The Bahamas ${ }^{1}$
}

\begin{abstract}
As an institution that has, since its inception, focused primarily on teaching rather than research, The College of The Bahamas has, following other Bahamian public institutions, not traditionally produced substantial empirical studies of Bahamian society and educational practices. Accordingly, this report presents the findings of a student exit survey of the largest first-year writing course at The College of The Bahamas, a study designed to measure students' perception of learning in the course. To facilitate comparison, the survey instrument generally followed publicly available survey studies of first-year composition students at other postsecondary institutions. While the exit survey suggests that students perceive the course as a whole to be beneficial for their development as academic writers, there is some evidence that students, in their responses to the survey, over-represented their learning in the class. Based on the data, the authors make several suggestions for improving student experience and outcomes in first-year writing courses at The College of The Bahamas. These suggestions include offering students more opportunities to learn library research strategies and building connections between writing instructors at the College of The Bahamas and secondary school English teachers in the Bahamas.
\end{abstract}

\section{Introduction}

Although college composition has been taught at postsecondary institutions in the Anglophone Caribbean for decades, little is known within the discipline of rhetoric and composition (a field dedicated to the systematic study of best practices in the teaching of postsecondary writing) regarding either the practices of college writing instructors in the Anglophone Caribbean or the unique issues faced by Anglophone
Caribbean students when taking college composition courses. Indeed, although the discipline of rhetoric and composition has not yet spread evenly throughout the Englishspeaking world - with the field's main centre of innovation and practice still being postsecondary institutions in the United States-there is an established tradition of teaching college composition at postsecondary institutions in the Anglophone Caribbean. This includes the flagship postsecondary

\footnotetext{
${ }^{1}$ Raymond A. Oenbring, Brianne Jaquette, Christine E. Kozikowski, \& Ivy Higgins, School of English Studies, The College of The Bahamas, P.O. Box N-4912, Nassau, Bahamas.

Acknowledgments: The authors would like to thank William Fielding, Anne Lawlor, and the anonymous reviewer for their help in the development of the study.

E-mail: raymond.oenbring@cob.edu.bs

APA reference: Oenbring, R. A., Jaquette, B., Kozikowski, C. E., \& Higgins, I. (2016). First-year English at the College of The Bahamas: Student perceptions. The International Journal of Bahamian Studies, 22, 43-53. http://dx.doi.org/10.15362/ijbs.v22i0.265
}

(CR. A. Oenbring, et al., 2016. Journal compilation (C)The International Journal of Bahamian Studies, 2016 
institution of the Commonwealth of the Bahamas, The College of The Bahamas (COB).

Since COB's establishment as a two-year college in the 1970s, its students have always taken two college composition courses in their first year, English 119 and English 120, a tradition that continues to the present. For years, English 119 focused specifically on exposition and 120 focused on argumentation, both construed in a traditional, narrow manner. This rigid dichotomy, stemming from the modes discourse taxonomy, has, since fall 2015, been abandoned. Now the distinction between the two classes revolves around the number of texts from which students are expected to synthesize information, with 119 having students work with single texts and 120 having students work with multiple texts.

Ongoing concern among both COB faculty and the broader Bahamian community regarding COB students' and graduates' continuing difficulties with writing Standard English eventually led to the development of a third English composition course, designed to be taken in the third year, specifically English 300/301. Developed as the institution started offering four-year degrees, English 300/301 was designed as a "refresher" academic writing course for both continuing matriculated students and for students with previous associate degrees returning to $\mathrm{COB}$ to upgrade to bachelor's degrees.

At present, COB students enrolled in bachelor's degree programmes take three English composition classes (English 119, 120, and 300) as part of their academic programmes, an English composition load significantly higher than that faced by students at most postsecondary institutions in North America. While the course numbers for the courses students take in their first year (119 and 120) have remained the same since
COB's founding, the guiding pedagogical approaches of these courses have changed considerably over the years; broadly stated, English 119 and 120 have, in line with developments in the North American tradition of rhetoric and composition, moved from a product-oriented, current-traditional approach relying heavily upon timed writing and a modes discourse taxonomy to a processdriven approach using portfolio assessment. Moreover, English 300, also originally using a modes discourse taxonomy, has recently been redesigned so that students spend time exploring the unique styles of writing used in their specific fields of study-that is, incorporating developments from the rhetoric and composition tradition of Writing in the Disciplines.

As an institution that has, for decades, focused almost exclusively on teaching rather than research, COB has produced very few empirical studies designed to assess the efficacy of its teaching practices and the outcomes of its classes. While the term outcomes is commonly used in the discipline of rhetoric and composition to refer to the explicitly defined list goals for first-year college writing courses published by the United States Council of Writing Program Administrators (2014), the present study, following the broad moves in educational assessment language and theory, uses the term outcomes in the more general sense of class results. Nonetheless, the survey instrument of the study is clearly informed by the values and goals of the WPA outcomes statement.

$\mathrm{COB}$, like many Bahamian public institutions, lacks baseline empirical data, whether publicly-available or not, to draw upon for making informed decisions about its practices and policies. While COB students complete teaching evaluations for most sections once per semester, these studies are lecturerfocused rather than programme-focused, and, 
more importantly, confidential. Furthermore, the dearth of academic publication by $\mathrm{COB}$ faculty likely feeds COB's image problem throughout The Bahamas, with many Bahamians preferring to study abroad over studying at $\mathrm{COB}$ and the government of The Bahamas spending millions of dollars per year on foreign consultant studies (Johnson, 2013) that could potentially be conducted by an adequately supported national research university. Beginning to fill this lack of empirical studies, this article presents the findings of an exit survey of students conducted by college composition faculty in November 2015. The exit survey, designed to measure student perceptions of learning during their first required first-year composition course, addressed the overarching research question: given the unique cultural and linguistic milieu of The Bahamas, how do $\mathrm{COB}$ students rate the efficacy of the current practices of $\mathrm{COB}$ writing instructors in building their academic writing skills?

\section{Literature Review}

Although little is known within the discipline of rhetoric and composition regarding current practices of college composition in the Anglophone Caribbean, Milson-Whyte's recent (2015) volume stands as a landmark study. In the book, Milson-Whyte provided an overview of the historical development of academic writing pedagogy at the University of the West Indies (UWI), the one preeminent regional doctoral-degree-granting institution in the Anglophone Caribbean, an institution that does provide some degree of regional consistency and regional education identity in the postcolonial Commonwealth Caribbean. Endorsing the use of writing instruction models that emphasize the writing process and disciplinary awareness in Anglophone Caribbean postsecondary institutions, MilsonWhyte noted in the volume that English writing instruction began at UWI in the 1960s, at the time of both UWI's movement to full university status and Jamaica's achieving political independence from Britain, as part of a general "Use of English" class which, following courses being developed in the United Kingdom at the time, seemingly focused more on teaching formal logic and oral presentation than on writing instruction (2015, p. 82-83). While English language instruction at UWI has become, through the importation of American-in-origin composition textbooks and through UWI faculty training in the United States, more centrally focused on teaching writing in the decades since, UWI has never fully adopted American (post-)process writing philosophy, retaining many product-oriented currenttraditional writing models (e.g., the modes). Moreover, UWI has retained in its writing instruction an emphasis on the rhetoric of excellence rather than access or equity, something that manifests itself in the Caribbean composition classroom in the form of grading standards that can appear punitive to American-trained faculty. For example, Rose and Sookraj (2015) revealed that the average grade in first-year Use of English class at the University of Guyana is D.

Several years before Milson-Whyte's magisterial study, Anderson and Irvine (1993) studied critical literacy among college composition students at the University of Virgin Islands (Lankshear, 1997) in the United States Virgin Islands. In The Bahamas specifically, the one extant study working within the rhetoric and composition tradition analyzing the peculiarities of teaching college composition within the local environment is Bruce (2015). Building upon her work on writing programme administration management strategies, Bruce critically assessed her experience working at and managing her American university's small Bahamian campus. In a different study, working within the tradition of applied 
linguistics, Bain (2005) quantitatively analyzed errors occurring in COB students' Standard English compositions stemming from the influence of their home language (Bahamian Creole English).

In Anglophone Caribbean postsecondary institutions there have been no published studies using student surveys to gauge the efficacy of college composition classes. While broad exit surveys of first-year composition programmes are, indeed, relatively rare in the published academic literature, writing programme administrators at several American postsecondary institutions have, in line with recent calls for more data-driven decision-making, produced official, publiclyavailable reports incorporating student exit surveys as part of their overall assessment of the state of their programmes (a 2013 report by the composition programme of the University of Alabama-Birmingham [UAB], Minnix and Mwenga, 2013). Indeed, in rhetoric and composition, there has, in recent years, been a broad move toward more empirical, data-driven approaches to the assessment of the programme outcomes of first-year writing. Arguing for data-intensive empirical studies of writing programmes, Lang and Behr (2012), for example, contended that

writing program administrators, faced with increasing demands for accountability and assessment, as well as widely varying student populations, need to have ways of understanding the interactions of students, faculty, and administrators in their present program, both in the short term and longitudinally (p. 173).

The developers of the present study believe student Internet surveys to be a time-efficient and cost-effective tool to support data-driven decision-making.
Although there is still an ongoing debate regarding the value of Internet surveys as a research method, with certain scholars (Fricker \& Schonlau, 2002) being more skeptical of the value and reliability of Internet surveys than others (Fenner et al., 2012), at least one study (Gosling, Vazire, Srivastava, \& John, 2004) has found that, while Internet surveys may have biases, these biases appear to be no greater than other surveys that rely upon self-selected participants. While Internet surveys are, indeed, likely a less-than-ideal research tool for scientifically accurate sampling, the relatively wide level of Internet access in The Bahamas (at least outside of the classroom) has made Internet surveys a popular research tool; there is an established body of academic publications in The Bahamas using Internet surveys as a research tool (Bethel, Minnis, \& Fielding, 2012; Oenbring \& Fielding, 2014). What is more, there is an established tradition in the Caribbean of using self-reported electronic surveys for research (UNAIDS Caribbean Regional Support Team, 2014). Nonetheless, drawing from the pioneering work of Bandura (1977, 1997)—whose studies also often used self-reported surveys - education scholars and rhetoric and composition scholars have both argued for the importance of students' self-belief in their abilities in furthering their learning, and have challenged the simple connection between student assessment of learning and student performance (Tripp, 2012).

\section{Methods}

For the study, a web-based questionnaire consisting of 20 closed-ended questions and one open-ended response was developed by the research team (see appendix A) and housed at popular web survey site SurveyMonkey.com. In order to facilitate quantitative analysis, the closed-ended questions were all on a Likert-scale (e.g., strongly agree $=4$, agree $=3$, neutral $=2$, 
disagree $=1$, strongly disagree $=0$ ). Specifically, students were asked to assess how much they agree with a variety of assertions regarding their learning and/or their development as writers during the course (e.g., this course helped me learn how to revise my papers). To facilitate comparison, most of the Likert-scale assertions in the survey instrument directly followed previous first-year composition exit surveys performed at other postsecondary institutions. For example, assertions 1-3 of the survey instrument followed the publicly-available UAB report. Other Likert-scale assertions followed a first-year composition survey developed at Southwest Minnesota State University in 2013 (see https://www. surveymonkey.com/r/?sm=hqKZC6xQJ4dDqj QC6fRmPg\%3d\%3d). Per international practice in research ethics, students not yet aged 18, or legally adults in The Bahamas, were not allowed to complete the survey. Following common practice at many postsecondary research institutions (Ferrari \& McGowan, 2002), some instructors offered students small completion bonus grades to encourage their participation in the study. Overall, students of four instructors from a total of eight sections of English 119 completed the survey at the end of Fall Semester 2015. The sample group of the study can thus be understood as a convenience sample. For each of the Likert-scale assertions, weighted means as well as standard deviations were calculated using SPSS.

Following several of the major concerns of the Council of Writing Program Administrators Outcomes Statement for FirstYear Composition (2014), the Likert-scale assertions in the survey instrument covered several different areas, including: critical reading (Q. 2. This course was effective in helping me learn skills for analyzing texts; $\mathrm{Q}$. 14. This course helped me analyze and/or critique my own writing; Q. 15. This course helped me analyze and/or critique the writing of others.); library research, incorporating sources, and documentation (Q. 1. This course was effective in helping me learn how to integrate sources and ideas from others into my own writing; Q. 8. This course helped me learn how to do library and online research; Q. 9. This course helped me learn how to document sources.); revision of essays (Q. 3. This course was effective in helping me respond effectively to writing assignments by writing multiple drafts and revising; Q. 10. This course helped me learn how to revise my papers.); planning and organization (Q. 4. This course helped me think about how to plan my writing; Q. 6. This course helped me organize my ideas and information.); identifying and fixing patterns of error in grammar and mechanics (Q. 12. This course helped me identify patterns of error that I make; Q. 13. This course helped me correct my writing.); effective deployment of evidence to support main ideas (Q. 5. This course helped me develop main ideas with specific details [such as examples, evidence, or statistics]); audience awareness (Q. 7. This course helped me consider the audience [reader] for my paper); and, finally, style and register choice $(\mathrm{Q}$. 11. This course helped me consider how to make appropriate style choices [such as choices about words, sentence length, and tone] when writing).

Other Likert-scale assertions in the survey were designed to measure students' overall impressions of whether they found the class to be an enfranchising and enabling experience (Q. 16. This course helped empower me to write.), and whether they believed their secondary English language classes prepared them for college writing (Q. 17. My English language classes in high school prepared me adequately for this class.). Other assertions were designed to both measure student perception of engagement in the class, and to 
serve as an indirect measure of students' honesty in their self-reporting in the study (Q. 18. I attended class regularly; Q. 19. I completed all of the work according to assignment requirements). The final Likertscale assertion was designed to measure whether students believe that the current student-teacher ratio of $1: 20$ is adequate for English composition courses (Q. 20. The teacher-to-student ratio was appropriate for me to receive adequate feedback and support.). Lastly, students were invited to provide whatever written feedback-directed

Table 1: Exit Survey Raw Results

\begin{tabular}{|c|c|c|c|c|c|c|c|}
\hline & $\begin{array}{c}\text { Strongly } \\
\text { Agree }\end{array}$ & Agree & Neutral & Disagree & $\begin{array}{l}\text { Strongly } \\
\text { Disagree }\end{array}$ & $\mathbf{M}$ & SD \\
\hline $\begin{array}{l}\text { 1. This course was effective in helping me } \\
\text { learn how to integrate sources and ideas } \\
\text { from others into my own writing. }\end{array}$ & 29 & 58 & 10 & 1 & 1 & 3.14 & 0.714 \\
\hline $\begin{array}{l}\text { 2. This course was effective in helping me } \\
\text { learn skills for analyzing texts. }\end{array}$ & 32 & 55 & 8 & 4 & 0 & 3.16 & 0.738 \\
\hline $\begin{array}{l}\text { 3. This course was effective in helping me } \\
\text { respond effectively to writing assignments } \\
\text { by writing multiple drafts and revising. }\end{array}$ & 38 & 47 & 11 & 3 & 0 & 3.21 & 0.76 \\
\hline $\begin{array}{l}\text { 4. This course helped me think about how } \\
\text { to plan my writing. }\end{array}$ & 41 & 39 & 18 & 0 & 1 & 3.20 & 0.808 \\
\hline $\begin{array}{l}\text { 5. This course helped me develop main } \\
\text { ideas with specific details (such as } \\
\text { examples, evidence, or statistics). }\end{array}$ & 35 & 43 & 19 & 2 & 0 & 3.12 & 0.786 \\
\hline $\begin{array}{l}\text { 6. This course helped me organize my } \\
\text { ideas and information. }\end{array}$ & 33 & 53 & 10 & 3 & 0 & 3.17 & 0.802 \\
\hline $\begin{array}{l}\text { 7. This course helped me consider the } \\
\text { audience (reader) for my paper. }\end{array}$ & 33 & 49 & 15 & 2 & 0 & 3.14 & 0.742 \\
\hline $\begin{array}{l}\text { 8. This course helped me learn how to do } \\
\text { library and online research. }\end{array}$ & 31 & 36 & 27 & 3 & 2 & 2.92 & 0.944 \\
\hline $\begin{array}{l}\text { 9. This course helped me learn how to } \\
\text { document sources. }\end{array}$ & 38 & 45 & 13 & 3 & 0 & 3.19 & 0.778 \\
\hline $\begin{array}{l}\text { 10. This course helped me learn how to } \\
\text { revise my papers. }\end{array}$ & 32 & 46 & 19 & 1 & 1 & 3.08 & 0.804 \\
\hline $\begin{array}{l}\text { 11. This course helped me consider how } \\
\text { to make appropriate style choices (such } \\
\text { as choices about words, sentence length, } \\
\text { and tone) when writing. }\end{array}$ & 34 & 44 & 18 & 1 & 0 & 3.14 & 0.75 \\
\hline $\begin{array}{l}\text { 12. This course helped me identify } \\
\text { patterns of error that I make. }\end{array}$ & 34 & 43 & 19 & 1 & 0 & 3.13 & 0.759 \\
\hline $\begin{array}{l}\text { 13. This course helped me correct my } \\
\text { writing. }\end{array}$ & 30 & 51 & 15 & 0 & 0 & 3.16 & 0.67 \\
\hline $\begin{array}{l}\text { 14. This course helped me analyze and/or } \\
\text { critique my own writing. }\end{array}$ & 30 & 49 & 17 & 1 & 0 & 3.11 & 0.72 \\
\hline $\begin{array}{l}\text { 15. This course helped me analyze and/or } \\
\text { critique the writing of others. }\end{array}$ & 30 & 44 & 20 & 3 & 0 & 3.04 & 0.803 \\
\hline $\begin{array}{l}\text { 16. This course helped empower me to } \\
\text { write. }\end{array}$ & 16 & 38 & 34 & 6 & 2 & 2.63 & 0.909 \\
\hline $\begin{array}{l}\text { 17. My English language classes in high } \\
\text { school prepared me adequately for this } \\
\text { class. }\end{array}$ & 20 & 32 & 26 & 13 & 6 & 2.48 & 1.147 \\
\hline 18. I attended class regularly. & 50 & 31 & 14 & 3 & 0 & 3.31 & 0.83 \\
\hline $\begin{array}{l}\text { 19. I completed all of the work according } \\
\text { to assignment requirements. }\end{array}$ & 38 & 44 & 15 & 1 & 0 & 3.21 & 0.736 \\
\hline $\begin{array}{l}\text { 20. The teacher-to-student ratio was } \\
\text { appropriate for me to receive adequate } \\
\text { feedback and support. }\end{array}$ & 58 & 32 & 6 & 1 & 0 & 3.52 & 0.663 \\
\hline
\end{tabular}


at the assignments and the design of the course itself rather than their instructor - they saw fit to volunteer in a final open-ended response (Q. 21. Not commenting on the specific style of your lecturer, please offer whatever feedback you may have on the design of this course and the assignments in the course).

\section{Results}

In total, the survey was completed by 99 students from eight different sections, with a relatively high overall response rate of $60 \%$. In line with COB School of English Studies' anecdotal overarching impression of student teaching evaluations, English 119 students, in general, expressed the view that the course was effective in building their academic writing skills and abilities, with most assertions having an average slightly higher than agree (i.e., in the 3.0-3.3 range). Assertions specifically regarding students' learning in the area of critical reading had an overall mean of 3.10. Similarly, assertions in the area of library research, incorporating sources, and documentation had a similar mean of 3.08. Assertions on the topics of revision of essays and identifying and fixing patterns of error in grammar and mechanics each had a slightly higher mean of 3.15. Moreover, assertions regarding planning and organization had an overall mean of 3.19. Table 1 presents student responses to the Likert-scale assertions, along with means and standard deviations. Unfortunately, few students took the time to thoughtfully and thoroughly complete the open-ended section, with most students $(N=60)$ writing nothing at all. Those students who did respond generally made comments directed at their lecturer (e.g., Dr. X really works with you.), despite being directed against this in the instructions, or short responses (e.g., great course). That is to say, generally, the open-ended responses were not insightful.

\section{Discussion}

The overall similarity in the means for the different Likert-scale assertions, as well as the overall lack of variation in the distribution of responses to the various assertions is suggestive; it indicates that students may have completed the survey without thorough contemplation of the different assertions. Moreover, there was some evidence that some students overrepresented their engagement and, perhaps, their learning in the course. This pattern was most clear in the means and response distributions for the two assertions meant to serve as indirect measures of students' honesty in their self-reporting in the study (Q. 18. I attended class regularly; Q. 19. I completed all of the work according to assignment requirements), with the student mean responses (3.31 and 3.21 respectively) far surpassing the levels of engagement that most English 119 professors would attribute to their students.

All in all, student responses were generally comparable to published student surveys of first-year writing at other colleges and universities. For example, student responses to the assertion this course was effective in helping me learn how to integrate sources and ideas from others into my own writing had a mean of 3.14 , whereas the parallel assertion in the UAB study had a mean of 3.18 when adjusted to the scale used in the current study. In fact, COB students expressed, on average, slightly stronger responses for the assertions this course was effective in helping me learn skills for analyzing texts and this course was effective in helping me respond effectively to writing assignments by writing multiple drafts and revising than found in the parallel assertions in the UAB study, with COB students' responses having averages of 3.16 and 3.21 and UAB students' responses having scaleadjusted averages of 2.96 and 3.01 
respectively. Interestingly, $\mathrm{COB}$ students expressed highest agreement with the statement the teacher-to-student ratio was appropriate for me to receive adequate feedback and support (average of 3.52), suggesting that 119 students believe that the current student-teacher ratio is appropriate for facilitating their learning.

However, students' responses averaged somewhat less than 3 for three different assertions, suggesting several areas where English composition faculty at $\mathrm{COB}$ and the institution as a whole may wish to focus attention in the future. The specific assertions with which students expressed somewhat less agreement on average were: my English language classes in high school prepared me adequately for this class $(M=2.48)$; this course helped empower me to write $(M=$ 2.63); and this course helped me learn how to do library and online research $(M=2.92)$.

The statement with the second-lowest rating (that is, this course helped empower me to write) suggests that many students do not view the class as an enabling or enfranchising experience. This finding accords with the general impression shared by many on COB's campus: that students, whether a product of their high school experience or otherwise, have a profound dislike for English language classes, a finding documented in other Anglophone Caribbean nations, such as Jamaica (Åberg \& Waller, 2012). That is to say, students, on average, find English language classes stifling rather than empowering, with many students avoiding taking required English composition courses until much later in their programme of study than COB advises. A similar trend was found at UWI, although the driving force there appears to be their fear of English and/or writing (Milson-White, 2015).

Finally, students also gave a low mean rating to the assertion this course helped me learn how to do library and online research. While this rating is not surprising given the fact that COB no longer provides systematic librariandriven library instruction or computerintegrated classrooms that English faculty can book for instructional purposes, it should be noted that many COB English faculty do their best to provide students with library instruction given the limited classroom and digital resources available. From the time of the institution's founding, $\mathrm{COB}$ required all students to complete a Library Orientation course taught by librarians to large groups of students in the College auditorium. Eventually, the Library Orientation course was cancelled with the intention of replacing it by incorporating library instruction into first-year English composition courses. While librarians did conduct one-hour sessions in first-year English composition classes at COB from 2008-2012, the library instruction programme was eventually cancelled, and, at present, most COB students receive little to no systematic library instruction as part of their academic programmes.

While COB's School of English Studies for years had a tradition of meeting with secondary school English Language teachers once a year for an information and training session facilitated by the Bahamian Ministry of Education, these meetings have recently been discontinued. Among other topics, these information and training sessions covered COB faculty's concerns about the reading and writing skills of incoming students and best practices in preparing college readers and writers. The fact that students gave the assertion my English language classes in high school prepared me adequately for this class the lowest average rating suggests that $\mathrm{COB}$ and the Ministry of Education may wish to revive and expand these meetings, with the goal of better preparing high-school students for the rigours of college writing. An example of a relatively simple improvement 
that high-school English Language teachers in The Bahamas could implement would be to increase the amount students write in essayistic and analytical genres rather than in narrative genres. Indeed, many Bahamian students do relatively little writing in analytical or essayistic genres in their highschool English language classes, as many English language teachers believe narrative writing to be an easier option for students for the Bahamian General Certificate of Secondary Education exam (BGCSE), The Bahamas' national high school exit exams, equivalent to O-level/GCSE in other Commonwealth nations.

\section{Limitations}

The authors recognize that this study had significant limitations. First, the survey was completed by the students of only four lecturers and by only eight sections of the more than 50 sections of English 119 offered per year. Also, as previously mentioned, there is some evidence that students overstated their degree of engagement and possibly learning in the course, in the various areas covered in Likert-scale assertions. This finding seemingly supports the line of research in rhetoric and composition and education studies more generally, which, following the work of Bandura $(1977,1997)$, challenges the correlation between students' self-assessment of their learning and their actual performance.

\section{Conclusion}

While anecdotal evidence suggests that College of The Bahamas students find English composition courses highly challenging, the exit survey indicates that students, as a whole, believe the course to be valuable for their learning as well as for their development as writers. This finding was supported both by students' closed-ended responses and by their written open-ended responses. This major finding, arrived at through rigorous data collection, reflects well upon the English composition programme at the College of The Bahamas and has the potential to provide both a positive public relations message for $\mathrm{COB}$ and support for COB's attempt to achieve international accreditation as it moves toward university status. Furthermore, the data presented in the study will prove valuable in the future for revision of English writing courses at COB.

Nonetheless, the data suggest that implementing a handful of improvements and adjustments could enhance the student experience in English 119. The authors of the study make the following recommendations for improving the student experience in and the course outcomes of COB's English composition courses. First of all, the College of The Bahamas should expand the availability of library instruction for English 119 students. Secondly, COB should maintain the current student-teacher ratio of 20 students per section in portfolio-based English composition courses. Thirdly, COB should conduct further research to evaluate strategies for reducing student distaste for and disengagement in English composition classes. Fourthly, COB should resume annual meetings between COB English faculty and high school teachers in The Bahamas and continue to foster this relationship in order to better prepare students for college writing at COB. And, finally, this study should be repeated, using the identical survey instrument in five years to gauge whether these changes have impacted student experience and course outcomes. 


\section{REFERENCES}

Åberg, A., \& Waller, J. (2012). English

language teachers' perception of their role and responsibility in three secondary schools in Jamaica (Undergraduate essay). Malmö University, Sweden. Retrieved from https://dspace.mah.se/bitstream/handle/204 3/13434/Dissertation\%20\%C5berg\%20\& $\%$ 20Waller\%20FINAL.pdf?sequence $=2$

Anderson, G., \& Irvine, P. (1993). Informing critical literacy with ethnography. In C. Lankshear \& P. McLaren (Eds.), Critical literacy, politics, praxis, and the postmodern (pp. 81-104). Albany: SUNY Press.

Bain, M. V. (2005). Language education and Bahamian students' compositions. College of The Bahamas Research Journal, 13, 423. http://dx.doi.org/10.15362/ijbs.v13i0.57

Bandura, A. (1977). Self-efficacy: Toward a unifying theory of behavioral change. Psychological Review, 84(2), 191-215. http://dx.doi.org/10.1037/0033295X.84.2.191

Bandura, A. (1997). Self-efficacy: The exercise of control. New York, NY: Freeman.

Bethel, N., Minnis, J., \& Fielding, W. J. (2012). Knowing your ancestors: A survey of Bahamians' knowledge of their progenitor's names. The International Journal of Bahamian Studies, 18, 1-5. http://dx.doi.org/10.15362/ijbs.v18i0.171

Bruce, S. (2015). So close, yet so far: Administering a writing program with a Bahamian campus. In D. Martins (Ed.), Transnational writing program administration (pp. 117-137). Boulder: University Press of Colorado.

Council of Writing Program Administrators.
(2014). WPA outcomes statement for firstyear composition (3.0), approved July 17, 2014. Retrieved from http://wpacouncil.org/positions/outcomes.h tml

Fenner, Y., Garland, S. M., Moore, E. E., Jayasinghe, Y., Fletcher, A., Tabrizi, S. N., Gunasekaran, B., \& Wark, J. D. (2012). Web-based recruiting for health research using a social networking site: An exploratory study. Journal of Medical Internet Research, 14, 1-19. http://dx.doi.org/ 10.2196/jmir.1978

Ferrari, J. R., \& McGowan, S. (2002). Using exam bonus points as incentive for research participation. Teaching Psychology, 29, 29-32. http://dx.doi.org/10.1207/S15328023TOP2 901_07

Fricker, R. D., \& Schonlau, M. (2002). Advantages and disadvantages of internet research surveys: evidence from the literature. Field Methods, 14, 347-367. http://dx.doi.org/10.1177/15258220223772 5

Gosling, S. D., Vazire, S., Srivastava, S., \& John, O. P. (2004). Should we trust webbased studies? A comparative analysis of six preconceptions about internet questionnaires. American Psychologist, 59(2), 93-104. http://dx.doi.org/10.1037/0003066X.59.2.93

Johnson, L. (2013, September 23). \$50M a year spent on foreign consultants. The Tribune. Retrieved from http://www.tribune242.com/news/2013/sep /23/50m-year-spent-foreign-consultants/

Lang, S., \& Behr, C. (2012). Data mining: A hybrid methodology for complex and dynamic research. College Composition and Communication, 64, 172-94. Retrieved from http://www.jstor.org/stable/23264925 
Lankshear, C. (1997). Changing literacies. Philadelphia, PA: Open University Press.

Milson-Whyte, V. (2015). Academic writing instruction for Creole-influenced students. Kingston, Jamaica: University of the West Indies Press.

Minnix, C., \& Mwenja, C. (2013). Freshman composition assessment data for WEAVE report, 2012-2013. Retrieved from http://www.uab.edu/2015compliancecertifi cation/IMAGES/SOURCEE509.PDF?id=a 14739da-9ce6-e311-b111-86539cf2d30e

Oenbring, R., \& Fielding, W. (2014). Young adults' attitudes to standard and nonstandard English in an English-Creolespeaking country: The case of The Bahamas. Language, Discourse \& Society, 3, 28-51. Retrieved from http://www.language-andsociety.org/journal/3-1/2_oenbring.pdf
Rose, P. V., \& Sookraj, R. (2015). Needs analysis: Undergraduates' evaluation of a university-wide English language course. Caribbean Educational Research Journal, 3, 62-75. Retrieved from http://www.cavehill.uwi.edu/fhe/education/ cerj/cerj-april-2015-june-01,-2015.aspx

Tripp, M. L. (2012). Engaging and enacting writing in first-year composition: reimagining student self-efficacy in writing (Unpublished doctoral dissertation). University of Central Florida, Orlando. Retrieved from http://etd.fcla.edu/CF/CFE0004447/Tripp_ Mary_L_201208_PhD.pdf

UNAIDS Caribbean Regional Support Team. (2014). CARIMIS: The Caribbean men's internet survey. Retrieved from http://unaidscaribbean.org/sites/default/file s/field/image/CARIMIS\%20REPORT\%20 2014_0.pdf 